\title{
Effect of starter nitrogen fertilizer on photosynthetic characters of relay strip intercropping soybean under drought stress
}

\author{
Jiang Liu', ${ }^{1, a}$, Jing Zhang ${ }^{2, b^{*}}$ \\ ${ }^{1}$ College of Agronomy, Sichuan Agricultural University, Chengdu, Sichuan, China \\ ${ }^{2}$ College of Horticulture, Sichuan Agricultural University, Chengdu, Sichuan, China \\ a335281212@qq.com, b123449792@qq.com, \\ ${ }^{*}$ Corresponding author
}

\begin{abstract}
Keywords: Starter nitrogen fertilizer, photosynthetic characters, relay strip intercropping soybean, drought stress

Abstract: A pot experiment was designed under drought stress condition to study the effect of different starter nitrogen fertilizer on photosynthetic characters in the leaves of relay strip intercropping soybean at branching stage. The Pn, Gs, Tr were measured, WUE was calculated. The results showed drought stress significantly decreased Pn, Gs and Tr. Mild drought stress reduced $\mathrm{Ci}$, moderate drought stress and severe drought stress increased $\mathrm{Ci}$. Under the same starter nitrogen fertilizer WUE was higher as the soil water content reduced. WUE of moderate drought stress was higher than that of mild drought stress, WUE of mild drought stress was higher than that of severe drought stress, and WUE of severe drought stress was higher than that of control. Appropriate starter nitrogen fertilizer was benefit to improve Pn, Gs and Tr, reduce Ci.
\end{abstract}

\section{Introduction}

Soybean is a species of legume widely grown for its edible bean which has numerous uses and is rather sensitive to water stress [1]. In order to increase land use efficiency which can produce a greater yield on a given piece of land by maximizing resources, wheat-corn/soybean relay strip intercropping system is popular in southwest China [2]. But because soybean under the system was affected by climate and hilly landforms, it always exposed to drought stress. In crop production, water is an important growth limiting factor and it is the most vital factor in physiological reaction at the same time [3]. Water stress could affect on plant's physiology, including growth [4], signaling pathways [5], gene expression [6] and leaf photosynthesis [7, 8]. Photosynthesis is an important determining factor of soybean yield [9]. Nitrogen for crop drought resistance has double role in water deficit [10]. Nitrogen is one of the major nutrients that are required for soybean growth and development. Starter nitrogen fertilizer benefited root activity, leaf photosynthesis, and consequently its yield [11].Therefore, under drought stress condition, pot experiment was conducted to study the effects of nitrogen on $\mathrm{Pn}, \mathrm{Ci}, \mathrm{Gs}$, Tr of relay intercropping soybean, and to provide an identification system for the study of soybean drought resistance, to provide theoretical basis and technical support in the application of nitrogen for soybeans.

\section{Materials and Methods}

Materials. Soybean cultivar Gongxuan No.1, a major component of southwestern soybean cultivars, was tested in the experiments. 
Experimental Design. The experiment was conducted in a relay strip intercropping system at the farm of

Sichuan Agricultural University. Soybean seeds were sown in the pots. Only three plants were allowed to grow per pot. Urea was dissolved in water for base fertilizer, and the tray in the pelvic floor was used to avoid the leaching of nitrogen after the rain. Each treatment was conducted with three replicates, and each replicate had 6 pots. Four nitrogen treatments were used $0 \mathrm{~g} \mathrm{~N} \mathrm{pot}^{-1}, 0.35$

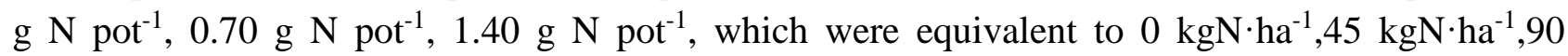
$\mathrm{kgN} \cdot \mathrm{ha}^{-1}, 180 \mathrm{kgN} \cdot \mathrm{ha}^{-1}$. Four drought stress treatments were imposed after the pots were moved in the shed, at the branching stage of soybean. 1/4 of the pots were kept continuously moist (WW, $75 \pm 2 \%$ of the field water capacity, short for FWC), and so did the light drought (LD, $60 \pm 2 \%$ of the field water capacity) and moderate drought (MD, $45 \pm 2 \%$ of the field water capacity) and severe drought (SD, $30 \pm 2 \%$ of the field water capacity). Soybean pots were placed under shade of maize to simulate light environment of the relay strip intercropping system of wheat-corn-soybean. Pots were moved into a shed with shading net at branching stage. The light under the net was $65 \%$ of environmental light. Net was moved, when maize in the field matured. The characters were determined 7 days after drought stress.

Photosynthetic parameters measurements. The net photosynthesis rate (Pn), stomatal conductance (Gs) and transpiration ( $\mathrm{Tr}$ ) were measured with a Portable Photosynthesis System (Model LI-6400, LI-COR Inc., Lincoln, NE). Water use efficiency (WUE) was calculated as Pn/Tr. The parameters were measured daily, after water stress was applied from 8:00 am to 12:00 am. Five plants were randomly chosen, and one of the most recently expanded leaves was selected from each plant four times. The photosynthetically active radiation (PAR), provided by an LED light source, was set to $1200 \mu \mathrm{mol} \mathrm{m} \mathrm{s}^{-2}$. The flow rate of air through the sample chamber was set at $500 \mu \mathrm{mol}^{-1}$ $\mathrm{s}^{-1}$, and the leaf temperature was maintained at $25 \pm 0.8^{0} \mathrm{C}$ by thermoelectric coolers. The $\mathrm{CO}_{2}$ concentration of the chamber was adjusted to $400 \mu \mathrm{ll}^{-1}$ with the system's $\mathrm{CO}_{2}$ injector.

Statistic analyses. Results were analyzed by two-way analysis of variance (LSD) and means were compared by Duncan's multiple range tests at $\mathrm{P}<0.05$. All data were organized in Excel (Microsoft) spread sheets and processed by the software Statistical Package for the Social Sciences (SPSS) version 11.5 .

\section{Results and Discussion}

Pn. From Table 1, it was found that drought stress significantly decreased Pn, and Pn was lower as the degree of drought stress became severely. Under the same nitrogen treatment, Pn was the highest at control (75\% of FWC), followed by mild stress ( $60 \%$ of FWC), and then moderate stress ( $45 \%$ of FWC), severe drought (30\% of FWC). Under control (75\% of FWC), appropriate N supply could increase Pn value, but differences of Pn among different $\mathrm{N}$ supply were not significant. Under $60 \%, 45 \%$ and $30 \%$ of FWC, appropriate N supply could significant increase Pn value. Under mild stress and moderate stress, Pn value was highest at $0.70 \mathrm{~g} \mathrm{~N}_{\text {pot }}^{-1}$, lowest at $0 \mathrm{~g} \mathrm{~N}_{\text {pot }}^{-1}$. Under severe stress Pn value was highest at $0.35 \mathrm{~g} \mathrm{~N} \mathrm{pot}^{-1}$, lowest at $1.40 \mathrm{~g} \mathrm{~N}$ pot $^{-1}$, which showed that when the soil water content was severely low, increase nitrogen application could not enhance Pn value, on the contrary Pn value decreased as the nitrogen application increased. 
Table 1 Effect of drought stress and nitrogen levels on $\mathrm{Pn}\left(\mu \mathrm{molCO} \mathrm{m}^{2-1} \mathrm{~s}^{-1}\right)$

\begin{tabular}{ccccc}
\hline Treatment & $0 \mathrm{~g} \mathrm{~N} \mathrm{pot}^{-1}$ & $0.35 \mathrm{~g} \mathrm{~N} \mathrm{pot}^{-1}$ & $0.70 \mathrm{~g} \mathrm{~N} \mathrm{pot}^{-1}$ & $1.40 \mathrm{~g} \mathrm{~N} \mathrm{pot}^{-1}$ \\
\hline $30 \%$ of FWC & $0.9187 \mathrm{~g}$ & $1.3553 \mathrm{~g}$ & $0.599 \mathrm{~h}$ & $0.5107 \mathrm{~h}$ \\
$45 \%$ of FWC & $3.5683 \mathrm{f}$ & $4.423 \mathrm{e}$ & $5.4501 \mathrm{e}$ & $3.7044 \mathrm{f}$ \\
$60 \%$ of FWC & $7.2227 \mathrm{~cd}$ & $9.3608 \mathrm{c}$ & $11.2961 \mathrm{~b}$ & $8.7658 \mathrm{c}$ \\
$75 \%$ of FWC & $14.0188 \mathrm{a}$ & $14.7867 \mathrm{a}$ & $15.9408 \mathrm{a}$ & $14.6445 \mathrm{a}$ \\
\hline
\end{tabular}

Note: The same small letters indicate the significant differences at $\mathrm{P}<0.05$, the same below.

Gs. The results showed that Gs reduced significantly when drought happened, and the Gs value was lower as the degree of drought stress became severely. Under the same nitrogen supply, the Gs value was highest at $75 \%$ of FWC, followed by mild stress, and then moderate stress, severe stress. Under $75 \%$ of FWC, Gs was highest at the treatment of $0.35 \mathrm{~g} \mathrm{~N} \mathrm{pot}^{-1}$. Under $60 \%$ of FWC Gs was highest at the treatment of $0.7 \mathrm{~g} \mathrm{~N} \mathrm{pot}^{-1}$. Under $45 \%$ of FWC Gs was highest at the treatment of 0.7 $\mathrm{g} \mathrm{N} \operatorname{pot}^{-1}$. Under $30 \%$ of FWC Gs was highest at the treatment of $0.35 \mathrm{~g} \mathrm{~N}^{-1}$.

Table 2 Effect of drought stress and nitrogen levels on Gs $\left(\mathrm{mmol} \mathrm{m}^{-2} \mathrm{~s}^{-1}\right)$

\begin{tabular}{cllll}
\hline Treatment & \multicolumn{1}{c}{$0 \mathrm{~g} \mathrm{~N} \mathrm{pot}^{-1}$} & \multicolumn{1}{c}{$0.35 \mathrm{~g} \mathrm{~N} \mathrm{pot}^{-1}$} & \multicolumn{1}{c}{$0.70 \mathrm{~g} \mathrm{~N} \mathrm{pot}^{-1}$} & \multicolumn{1}{c}{$1.40 \mathrm{~g} \mathrm{~N} \mathrm{pot}^{-1}$} \\
\hline $30 \%$ of FWC & $0.0037 \mathrm{e}$ & $0.0060 \mathrm{~d}$ & $0.0037 \mathrm{e}$ & $0.0036 \mathrm{e}$ \\
$45 \%$ of FWC & $0.0065 \mathrm{~d}$ & $0.0114 \mathrm{~cd}$ & $0.0117 \mathrm{~cd}$ & $0.0124 \mathrm{~cd}$ \\
$60 \%$ of FWC & $0.0160 \mathrm{~cd}$ & $0.0265 \mathrm{c}$ & $0.0367 \mathrm{~b}$ & $0.0217 \mathrm{c}$ \\
$75 \%$ of FWC & $0.0462 \mathrm{~b}$ & $0.0966 \mathrm{a}$ & $0.0900 \mathrm{a}$ & $0.0702 \mathrm{ab}$ \\
\hline
\end{tabular}

Ci. We observed a reduction and then an increase in $\mathrm{Ci}$ under the same nitrogen supply when soil water content reduced. Under the same nitrogen supply, the $\mathrm{Ci}$ value was lowest at mild stress, followed by control, and then moderate stress, severe stress. Under $75 \%, 60 \%, 45 \%$ and $30 \%$ of FWC, Ci was lowest at the treatment of $0.7 \mathrm{~g} \mathrm{~N} \mathrm{pot}^{-1}$, and was highest at the treatment of $0 \mathrm{~g} \mathrm{~N}$ $\operatorname{pot}^{-1}$.

Table 3 Effect of drought stress and nitrogen levels on $\mathrm{Ci}\left(\mathrm{mg} \mathrm{kg}^{-1}\right)$

\begin{tabular}{ccccc}
\hline Treatment & $0 \mathrm{~g} \mathrm{~N} \mathrm{pot}^{-1}$ & $0.35 \mathrm{~g} \mathrm{~N} \mathrm{pot}^{-1}$ & $0.70 \mathrm{~g} \mathrm{~N} \mathrm{pot}^{-1}$ & $1.40 \mathrm{~g} \mathrm{~N} \mathrm{pot}^{-1}$ \\
\hline $30 \%$ of FWC & $578.03 \mathrm{a}$ & $458.67 \mathrm{~b}$ & $448.09 \mathrm{~b}$ & $537.90 \mathrm{ab}$ \\
$45 \%$ of FWC & $449.71 \mathrm{~b}$ & $338.99 \mathrm{c}$ & $241.72 \mathrm{cde}$ & $325.36 \mathrm{~cd}$ \\
$60 \%$ of FWC & $235.18 \mathrm{de}$ & $230.66 \mathrm{de}$ & $186.60 \mathrm{e}$ & $210.99 \mathrm{e}$ \\
$75 \%$ of FWC & $251.48 \mathrm{cde}$ & $241.89 \mathrm{cde}$ & $238.41 \mathrm{cde}$ & $247.49 \mathrm{cde}$ \\
\hline
\end{tabular}

Tr. The results showed that Tr reduced as the soil water content decreased. Under the same nitrogen supply, the Tr value was highest at $75 \%$ of FWC, followed by mild stress, and then moderate stress, severe stress. Under 75\%,60\% and $45 \%$ of FWC, Tr was lowest at the treatment of $0 \mathrm{~g} \mathrm{~N}$ pot $^{-1}$, and was highest at the treatment of $0.7 \mathrm{~g} \mathrm{~N}$ pot $^{-1}$. Under $30 \%$ of $\mathrm{FWC}, \mathrm{Tr}$ was lowest at the treatment of $0 \mathrm{~g} \mathrm{~N}$ pot $^{-1}$, and was highest at the treatment of $0.35 \mathrm{~g} \mathrm{~N}$ pot $^{-1}$.

Table 4 Effect of drought stress and nitrogen levels on $\operatorname{Tr}\left(\mathrm{mmol} \mathrm{m}^{-2} \mathrm{~s}^{-1}\right)$

\begin{tabular}{ccccc}
\hline Treatment & $0 \mathrm{~g} \mathrm{~N} \mathrm{pot}^{-1}$ & $0.35 \mathrm{~g} \mathrm{~N} \mathrm{pot}^{-1}$ & $0.70 \mathrm{~g} \mathrm{~N} \mathrm{pot}^{-1}$ & $1.40 \mathrm{~g} \mathrm{~N} \mathrm{pot}^{-1}$ \\
\hline $30 \%$ of FWC & $0.15 \mathrm{~d}$ & $0.23 \mathrm{~d}$ & $0.15 \mathrm{~d}$ & $0.16 \mathrm{~d}$ \\
$45 \%$ of FWC & $0.39 \mathrm{~d}$ & $0.51 \mathrm{~d}$ & $0.60 \mathrm{~d}$ & $0.48 \mathrm{~d}$ \\
$60 \%$ of FWC & $0.80 \mathrm{~cd}$ & $1.21 \mathrm{~cd}$ & $1.68 \mathrm{c}$ & $1.03 \mathrm{~cd}$ \\
$75 \%$ of FWC & $2.96 \mathrm{~b}$ & $3.95 \mathrm{a}$ & $3.97 \mathrm{a}$ & $3.81 \mathrm{ab}$ \\
\hline
\end{tabular}


WUE. The results showed that mild drought and moderate drought can increase WUE under four nitrogen treatments. Under $0 \mathrm{~g} \mathrm{~N}^{-1}$ and $0.35 \mathrm{~g} \mathrm{~N}^{-1}$ pot $^{-1}$ treatments severe drought could also enhance WUE. WUE of severe drought reduced under $0.7 \mathrm{~g} \mathrm{~N} \mathrm{pot}^{-1}$ and $1.4 \mathrm{~g} \mathrm{~N}_{\text {pot }}{ }^{-1}$ treatments. Under $0 \mathrm{~g} \mathrm{~N}_{\text {pot }}^{-1}$ and $0.35 \mathrm{~g} \mathrm{~N}$ pot $^{-1}$, WUE was highest at moderate stress, followed by mild stress, and then severe stress, control. Under $0.7 \mathrm{~g} \mathrm{~N} \mathrm{pot}^{-1}$, WUE was highest at moderate stress, followed by mild stress, and then control, severe stress. Under $1.4 \mathrm{~g} \mathrm{~N} \mathrm{pot}^{-1}$, WUE was highest at mild stress, followed by moderate stress, and then control, severe stress.

Table 5 Effect of drought stress and nitrogen levels on WUE

\begin{tabular}{ccccc}
\hline Treatment & $0 \mathrm{~g} \mathrm{~N} \mathrm{pot}^{-1}$ & $0.35 \mathrm{~g} \mathrm{~N} \mathrm{pot}^{-1}$ & $0.70 \mathrm{~g} \mathrm{~N} \mathrm{pot}^{-1}$ & $1.40 \mathrm{~g} \mathrm{~N} \mathrm{pot}^{-1}$ \\
\hline $30 \%$ of FWC & $6.12 \mathrm{c}$ & $5.89 \mathrm{~cd}$ & $3.99 \mathrm{de}$ & $3.19 \mathrm{e}$ \\
$45 \%$ of FWC & $9.15 \mathrm{a}$ & $8.67 \mathrm{ab}$ & $9.08 \mathrm{a}$ & $7.72 \mathrm{~b}$ \\
$60 \%$ of FWC & $9.03 \mathrm{a}$ & $7.74 \mathrm{~b}$ & $6.72 \mathrm{c}$ & $8.51 \mathrm{ab}$ \\
$75 \%$ of FWC & $4.74 \mathrm{~d}$ & $3.74 \mathrm{de}$ & $4.02 \mathrm{de}$ & $3.84 \mathrm{de}$ \\
\hline
\end{tabular}

\section{Conclusion}

Stomatal closure primarily causes a decline in the photosynthesis rate [12]. The variation in $\mathrm{Ci}$ can be used as a standard to estimate the reasons for decreased Pn, and whether decreases in Gs or reductions of mesophyll can result in changes in the cell's photosynthetic capacity. In this study, we observed a decrease in Gs and increase in $\mathrm{Ci}$ in the moderate drought and severe drought stressed plants. These results suggest that the strong decrease in Pn in mild drought-stressed plants may be caused by the closure of stomata. Reduction of moderate and severe drought-stressed plants in the photosynthetic capacity of mesophyll cells, which in turn results in increased Ci. Appropriate starter nitrogen fertilizer was benefit to improve Pn, Gs and Tr, reduce Ci.

\section{References}

[1] Ohashi Y, Nakayama N, Saneoka H, et al. Effects of drought stress on photosynthetic gas exchange, chlorophyll fluorescence and stem diameter of soybean plants. Biologia Plantarum, 2006, 50(1): 138-141.

[2] Tilman D, Cassman K G, Matson P A, et al. Agricultural sustainability and intensive production practices. Nature, 2002, 418(6898): 671.

[3] Hazrati S, Tahmasebi-Sarvestani Z, Modarres-Sanavy S A M, et al. Effects of water stress and light intensity on chlorophyll fluorescence parameters and pigments of Aloe vera L. Plant Physiology and Biochemistry, 2016, 106: 141-148.

[4] McDonald A J S, Davies W J. Keeping in Touch: Responses of the Whole Plant to Deficits. Advances in Botanical Research, 1996, 22: 229.

[5] Chaves M M, Maroco J P, Pereira J S. Understanding plant responses to drought-from genes to the whole plant. Functional plant biology, 2003, 30(3): 239-264.

[6] Bray E A. Plant responses to water deficit. Trends in plant science, 1997, 2(2): 48-54.

[7] Lawlor D W, Cornic G. Photosynthetic carbon assimilation and associated metabolism in relation to water deficits in higher plants. Plant, cell \& environment, 2002, 25(2): 275-294.

[8] Flexas J, Medrano H. Energy dissipation in $\mathrm{C}_{3}$ plants under drought. Functional Plant Biology, 2002, 29(10): 1209-1215.

[9] Wang L, Zhang T, Ding S. Effect of drought and rewatering on photosynthetic physioecological 
characteristics of soybean. Acta Ecologica Sinica, 2006, 26(7): 2073-2078.

[10]Sun Qun, Liang Zong-suo, Wang Wei-ling, Li Xue-jun, Zhang Fu-suo. Effect of Membrane Lipid Peroxidation and Photosynthesis Rate on Water Stress under Different Nitrogen Level in Maize. Acta Agriculturae Boreali-occidentalis Sinica. 2001, 10(1): 7- 10. (in Chinese)

[11]Gai Z, Zhang J, Li C. Effects of starter nitrogen fertilizer on soybean root activity, leaf photosynthesis and grain yield . PloS one, 2017, 12(4): e0174841.

[12] Mahajan S, Tuteja N. Cold, salinity and drought stresses: an overview. Archives of biochemistry and biophysics, 2005, 444(2): 139-158. 